\title{
A new large and colourful species of the genus Doto (Nudibranchia: Dotidae) from South Africa
}

\author{
Marta Pola ${ }^{\mathrm{a}, \mathrm{b} *}$ and Terrence M. Gosliner ${ }^{\mathrm{b}}$ \\ ${ }^{a}$ Departamento de Biología, Universidad Autónoma de Madrid, Madrid, Spain; ${ }^{b}$ California \\ Academy of Sciences, San Francisco, USA
}

(Received 17 December 2014; accepted 22 March 2015; first published online 6 May 2015)

\begin{abstract}
A new species of the genus Doto is described from the Cape Peninsula of the Western Cape Province, South Africa. To date, the genus Doto is probably one of the more complex and poorly defined genera within nudibranchs. The very small body size and very similar external and internal features make this genus problematic and, therefore, poorly studied. Despite the large number of described species around the world, only three species are known to be present in South Africa: Doto coronata (Gmelin, 1791), Doto pinnatifida (Montagu, 1804) and Doto rosea Trinchese, 1881. Morphologically, Doto splendida sp. nov. is easily distinguished from all its South African congeneric species by its conspicuous colouration. In addition, mitochondrial and nuclear genes clearly separate the new species from other species from southern Africa. A molecular phylogeny based on two mitochondrial (COI and 16S) and one nuclear (H3) gene is herein presented. This phylogeny includes all available species of Doto (valid and unidentified) as well as several other traditionally closed related species retrieved from GenBank.
\end{abstract}

http://zoobank.org/urn:1sid:zoobank.org:pub:3764C38DF6BB-415F-958CE3132A1A9524

Keywords: Cape Peninsula; Heterobranchia; molecular phylogeny; Mollusca; new species; taxonomy

\section{Introduction}

The genus Doto Oken, 1815 includes 93 species, of which 75 are considered valid (WORMS: http://www.marinespecies.org/aphia.php?p=taxdetails\&id=137916). Most of these species have not been completely described; most lack any detailed description of the reproductive system and often there has been no description of the radula. Most species appear to have relatively narrow distributions, but several species are more widely distributed. For example, Doto ussi Ortea, 1982 is known from the western Indian Ocean to the western Pacific (Gosliner et al. 2008). While many species have been recorded from the temperate north-eastern Atlantic (e.g. Lemche 1976; Ortea and Bouchet 1989; Morrow et al. 1992), relatively few species have been documented from the temperate south-eastern Atlantic (Gosliner 1987). The three species that have been recorded from the coast of southern Africa are all species that are also known from the north Atlantic: Doto coronata (Gmelin, 1791), Doto pinnatifida (Montagu, 1804) and Doto rosea Trinchese, 1881. While it is assumed that these are conspecific with European taxa (Gosliner 1987), no detailed anatomical or

*Corresponding author. Email: marta.pola@uam.es 
molecular studies have confirmed this. Most of the descriptions are based solely on external morphology, and mainly the details of coloration, and it is unclear how definitive external features are in Dotidae. Additionally, the lack of detailed descriptions of anatomical structures, such as the radula and the reproductive system, at present does not permit a determination of how definitive these internal structures are in determining species boundaries and delimitation.

This paper provides precise and detailed description of a new species of Doto, recently collected along the False Bay coast of Cape Peninsula, South Africa. Scanning electron micrograph (SEM) pictures of the radula and penis in addition to a drawing of the reproductive system are included. This taxon, although clearly assignable to the genus Doto, is different from the other species of the genus. Its coloration is strongly divergent from the rest of the species of the genus and its external morphology is also unlike any other taxon. These external features, together with some internal features and molecular data, characterize it as a very interesting and remarkable new species of this genus. Since the goal of this study is not to conduct a review of the genus Doto, the new species is compared only with species of the genus reported for the same geographic area and others that have similar anatomical features, where the anatomy is known. Molecular data for the new species obtained by Pola and Gosliner (2010) are also included in a small phylogeny based on molecular data available in GenBank.

\section{Material and methods}

Specimens of the new species were obtained from museum samples deposited in the California Academy of Sciences Department of Invertebrate Zoology and Geology in San Francisco (CASIZ). Features of living animals were recorded from photographs. Specimens were dissected under a microscope and external and internal features were recorded. The buccal mass was extracted and soaked in a $10 \%$ sodium hydroxide solution to dissolve the connective and muscle tissue, leaving only the radula and mandibles. The penis was critical point dried. The coated radula, jaws and penis of each species were examined and images were obtained using SEM (Leo 1450 VP, Carl Zeiss Inc., Oberkochen, Germany).

Phylogenetic trees were obtained using all available species of Doto (valid and unidentified) in GenBank. Six new specimens were sequenced following the same protocol as in Pola and Gosliner (2010). All species used in this study, localities, vouchers and GenBank accession numbers for partial sequences of the mitochondrial genes cytochrome $c$ oxidase subunit I and 16S rRNA, and the nuclear gene histone 3 are found in Table 1.

DNA sequences were assembled and edited using Geneious Pro 4.7.6 (Drummond et al. 2009). The alignments were checked by eye using MacClade 4.06 (Maddison and Maddison 2005). Protein-coding sequences were translated into amino acids for confirmation of alignment. Pairwise uncorrected p-distance values between each taxon were calculated for the COI gene using PAUP* 4.0b 10.0 (Swofford 2002). All codon positions were considered for the analysis. The most variable regions from $16 \mathrm{~S}$ rRNA alignments were removed using both the default settings and the standard options for stringent and less stringent selection in GBLOCKS (Castresana 2000) and MAFFT (Katoh et al. 2009). After primer removal, sequences of $\mathrm{COI}, 16 \mathrm{~S}$, and $\mathrm{H} 3$ were trimmed to 658, 486 (including 


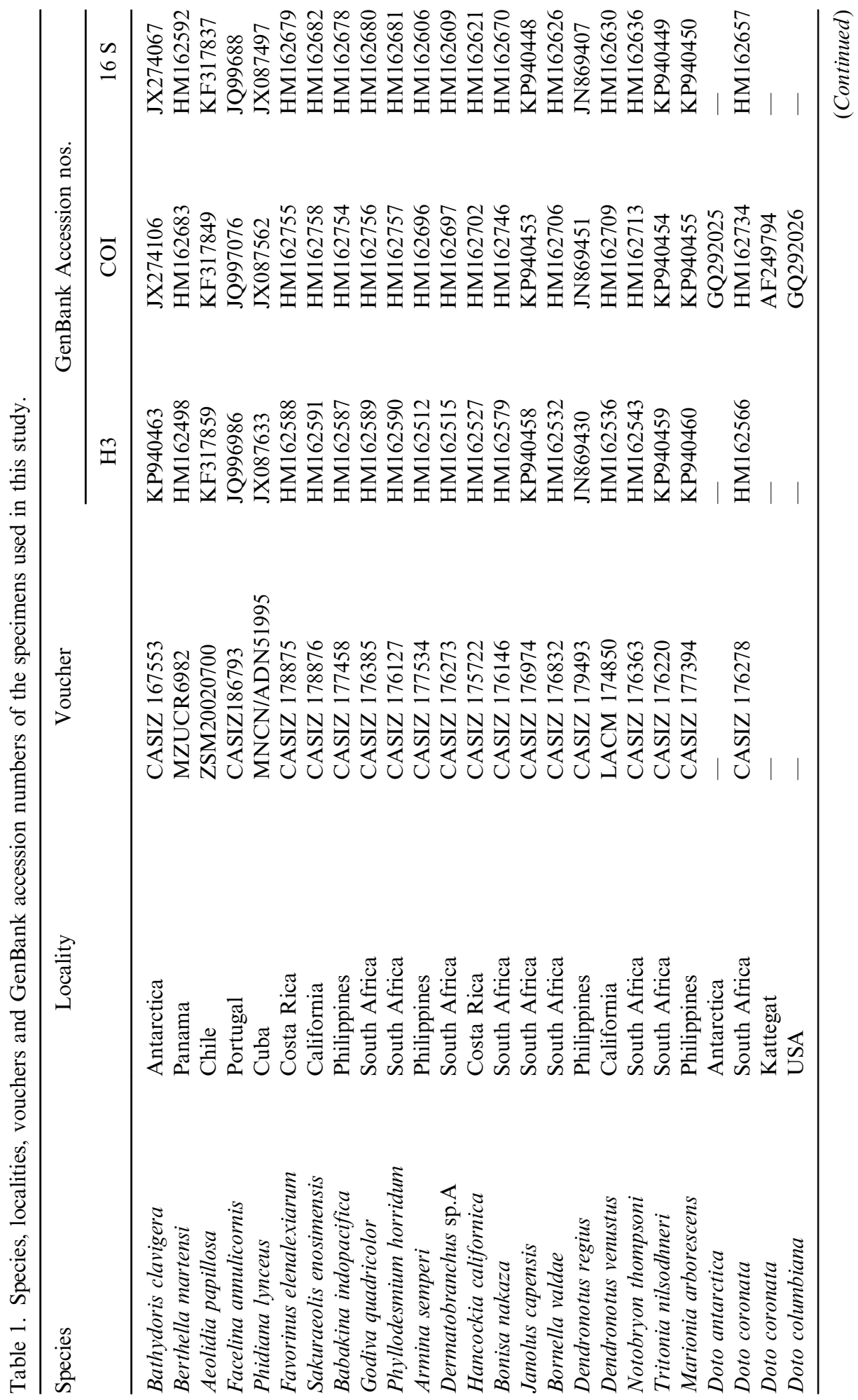




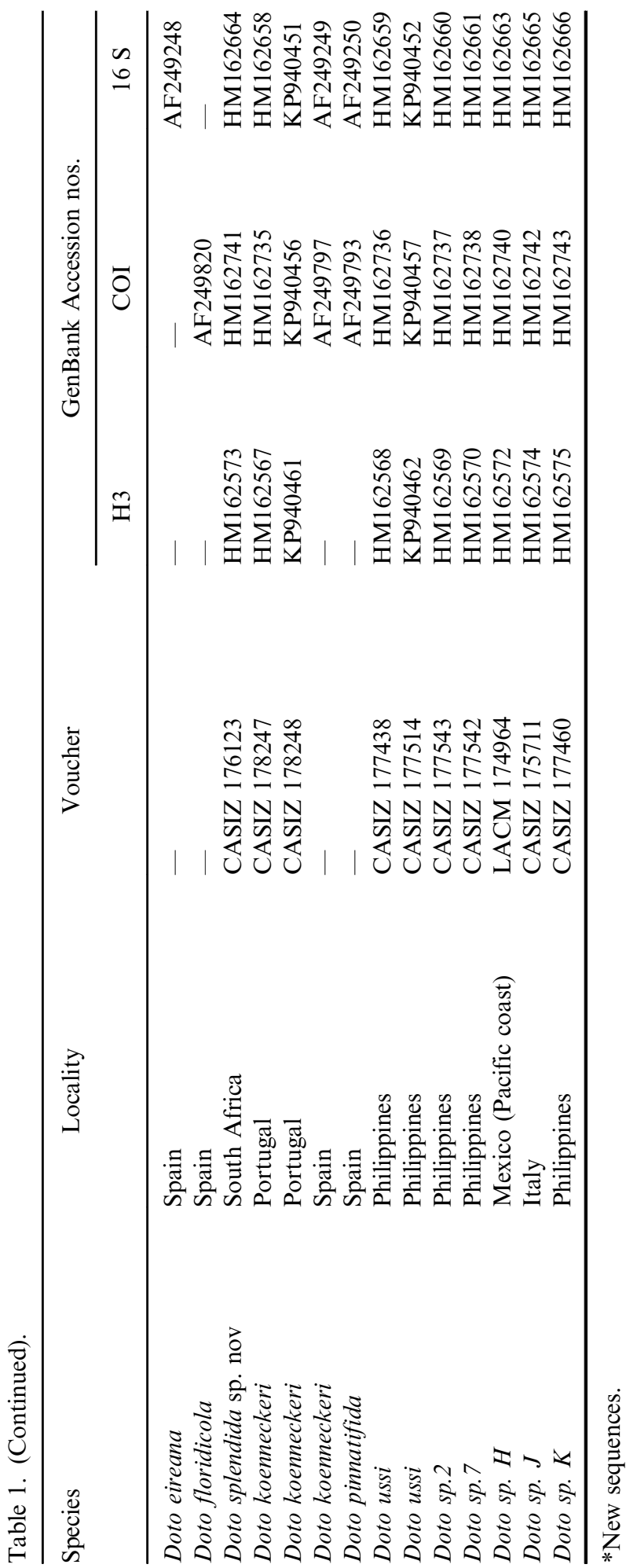


gaps), and 328 base pairs, respectively. The tree resulting from the trimmed $16 \mathrm{~S}$ sequences was poorly resolved and had lower node support.

Individual gene analyses and a concatenated analysis were performed. The best-fit models for evolution for each gene were determined using the Akaike information criterion (Akaike 1974) implemented in MrModeltest 2.3 (Nylander 2004). The GTR $+\mathrm{G}+\mathrm{I}$ model was selected for COI and $16 \mathrm{~S}$ genes. GTR $+\mathrm{G}$ was selected for H3.

Maximum likelihood (ML) analyses were performed using the software RAxML 7.04 (Stamatakis 2006). Node support was assessed with non-parametric bootstrapping (BS) with 50,000 replicates, random starting trees, and parameters estimated from each data set under the model selected for the original data set. Bayesian inference (BI) analyses were conducted using MrBayes 3.1.2b (Ronquist and Huelsenbeck 2003) for 10 million generations with two independent runs and a sampling frequency of 1000 . The models implemented were those estimated with MrModeltest 2.3. The combined data set was partitioned among genes, and the 'unlink' command was used to allow all parameters to vary independently within each partition. Node support was assessed with posterior probabilities (PPs). Only nodes supported by $\mathrm{BS} \geq 75$ and $\mathrm{PP} \geq 0.95$ are considered robust and discussed.

\title{
Systematics
}

\author{
Class GASTROPODA Cuvier, 1795 \\ Order NUDIBRANCHIA Cuvier, 1817 \\ Suborder DEXIARCHIA Schrödl et al. 2001 \\ Family DOTIDAE Gray, 1853 \\ Genus Doto Oken, 1815
}

Type species: Doris coronata Gmelin, 1791. ICZN opinion no. 697

Doto splendida sp. nov.

(Figures 1-3)

Doto sp. I Pola and Gosliner, 2010: 935

\section{Type material}

Holotype: adult specimen, $5 \mathrm{~mm}$ preserved (South Africa, western Cape Province, western False Bay, Miller's Point, 34¹3.84'S, $18^{\circ} 28.47^{\prime} \mathrm{E}$; intertidal, found feeding on Eudendrium [California Academy of Sciences (CASIZ176124)]. Collected by T.M. Gosliner, 3 January 2008.

Paratype: one adult specimen completely dissected and sequenced for molecular studies, $20 \mathrm{~mm}$ alive $(10 \mathrm{~mm}$ preserved), water depth: $3 \mathrm{~m}$ (same locality, date and collector as holotype) [CASIZ176123]. 

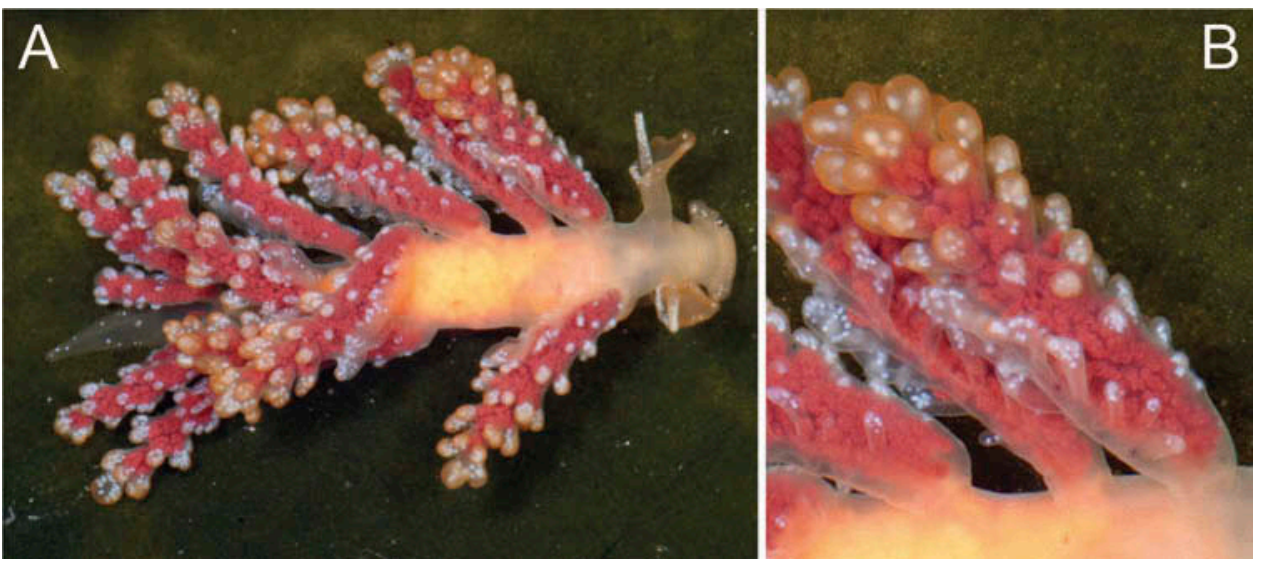

Figure 1. Doto splendida nov. sp. Paratype (CASIZ176123), South Africa, western Cape Province, western False Bay, Miller's Point. $20 \mathrm{~mm}$ in length. Photo by T.M. Gosliner. (A) Living animal; (B) detail of a cera.

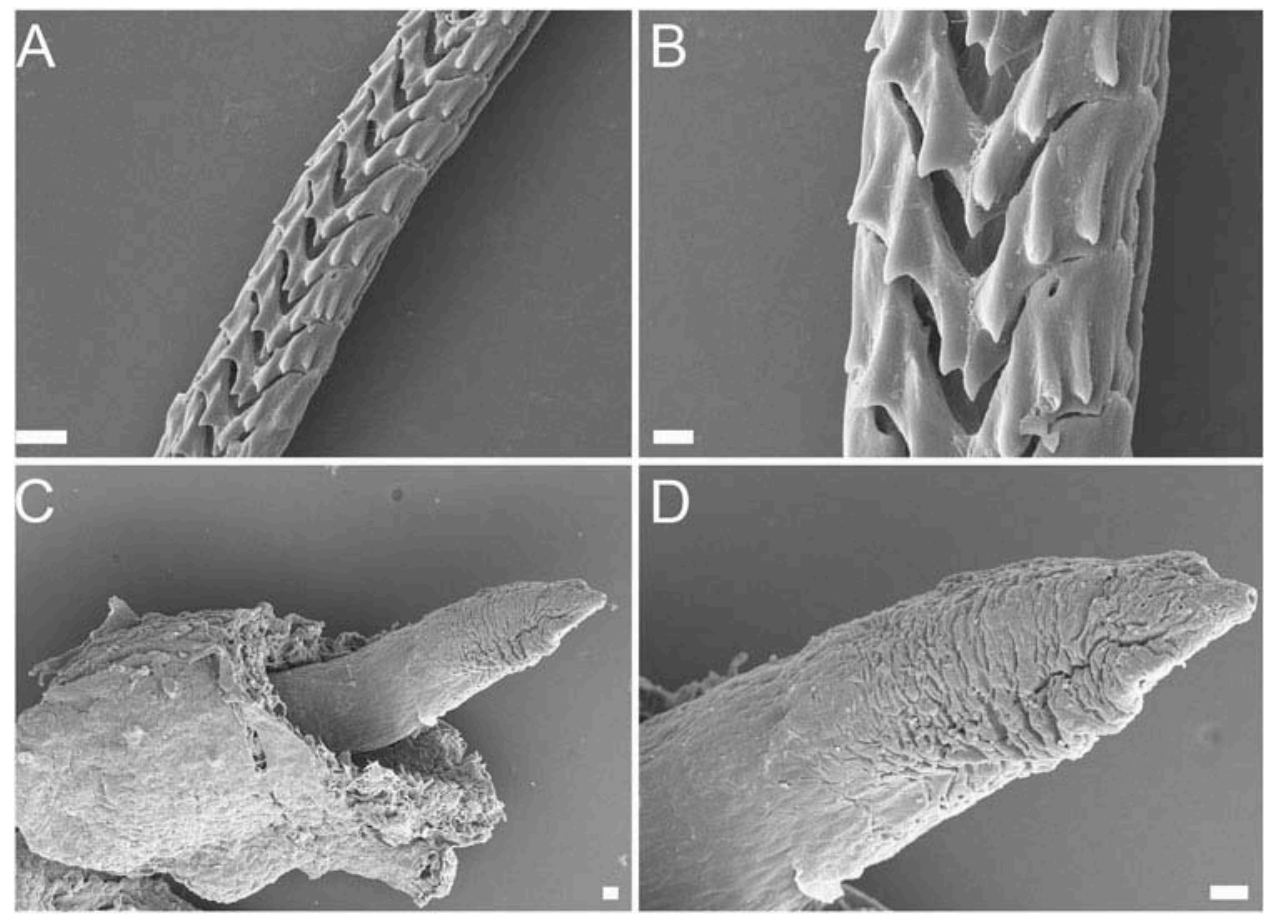

Figure 2. Doto splendida nov. sp. Paratype (CASIZ176123), SEM pictures of the radula and penis. (A) Radula, scale bar: $10 \mu \mathrm{m}$; (B) detail of the teeth, scale bar: $3 \mu \mathrm{m}$; (C) penis, scale bar: $10 \mu \mathrm{m}$; (D) detail of the penis, scale bar: $10 \mu \mathrm{m}$. 


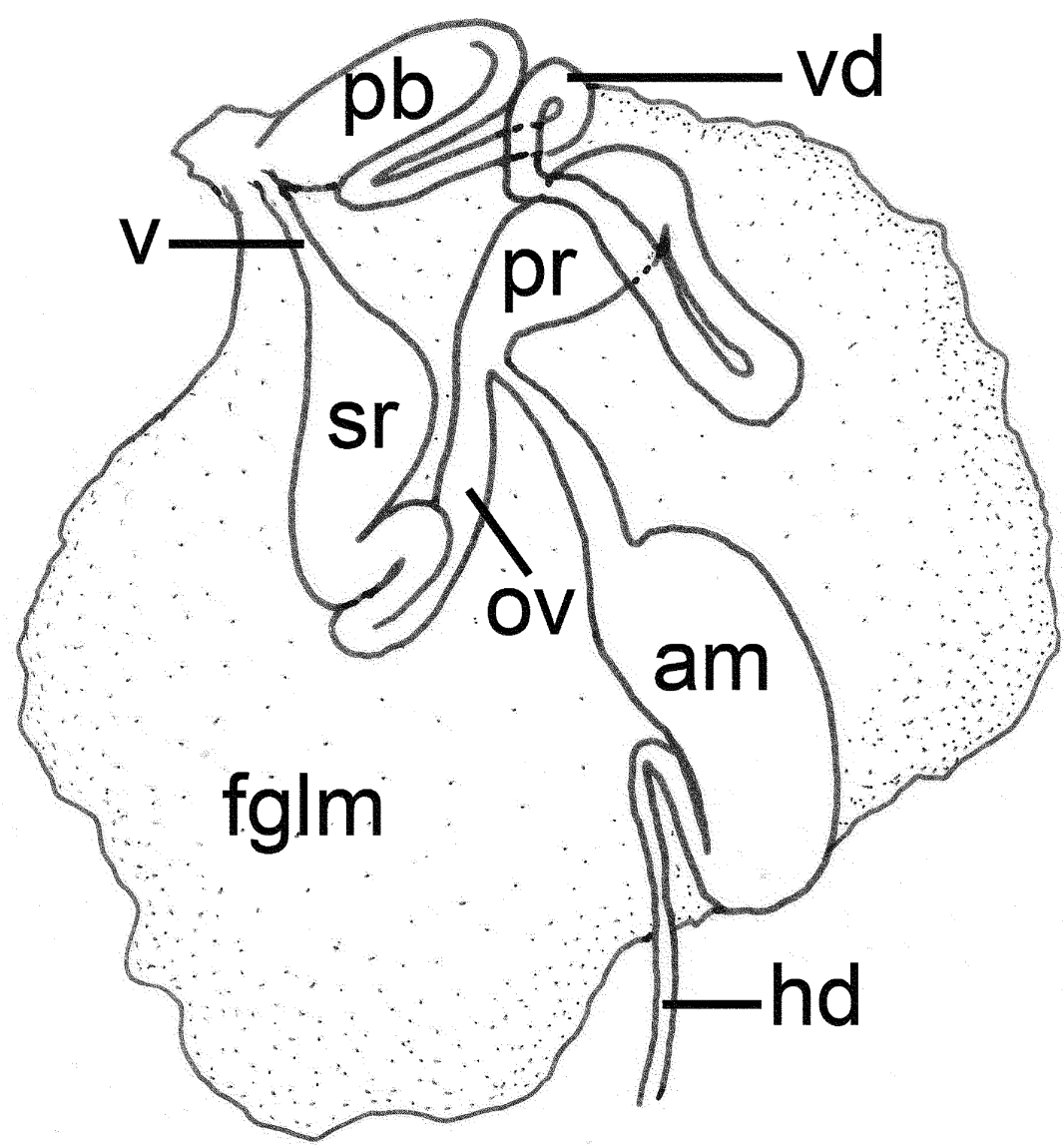

Figure 3. Reproductive system of Doto splendida nov. sp. Paratype (CASIZ176123). Abbreviations: am, ampulla; fglm, female gland mass; hd, hermaphrodite duct; ov, oviduct; pb, penial bulb; pr, prostate; sr, seminal receptacle; v, vagina; vd, vas deferens. Scale bars, $1 \mathrm{~mm}$.

\section{Etymology}

The specific name refers to the beautiful and conspicuous colour of the animal. From the Latin word splendidus, meaning brilliant, magnificent appearance.

\section{Distribution}

Thus far this species is only known from Western Cape Province, South Africa.

\section{External morphology (Figure 1)}

The body is slender and elongate (Figure 1A). Its length reaches $20 \mathrm{~mm}$ alive. The head bears a pair of smooth rhinophores with blunt apices, surrounded by 
rhinophoral sheaths that reach half of the total length of the rhinophores in living specimens (Figure 1A). The sheaths are rather slender, the diameter being double that of the rhinophore itself. Above, the sheaths are undulate, trumpet-shaped with their anterior side ending with a rather long, tongue-like projection at the upper end (Figure 1A). A wide oral veil is present in front of the rhinophores. It is entire, rounded and expanded laterally, without projections. On each side of the body, up to 7 cerata occur, the hindmost usually being smaller than the anterior and middle cerata. The cerata are large, elongate, with rounded tubercles that decrease in size basally towards the body. The base of the cerata is not pedunculate. Each ceras bears six or seven rings of six-seven simple or more complex semiglobular tubercles and one larger tubercle at the top (Figure 1A, B). At the inner side of a ceras a pseudobranch is situated with $4-5$ ramifications of varying lengths. The genital opening is located slightly below and in front of the first ceras on the right side, and protrudes as a cylindrical genital papilla. On this side, between the first and second cerata, the anus and nephroproct together form a prominent papilla. The pericardium starts just behind the first ceras. The posterior end of the foot is long and limaciform (Figure 1A). The posterior end of the foot is narrow and extends slightly from under the mantle. The pericardium forms a swelling on the back, between the first and second cerata.

Colouration (Figure 1). The body is transparent, with a faint orange hue covered with occasional small opaque white dots dispersed over the frontal veil, the upper half of the rhinophores, the borders of their sheaths, the posterior end of the foot and the tubercles of the cerata. The yellow digestive gland is clearly visible through the transparent faint orange body wall. The branches of the digestive gland in the cerata are intense pink. The tubercles of the cerata are faint orange, similar to the ground colour with small white dots more or less abundant (Figure 1A, B). The foot is transparent.

\section{Internal anatomy (Figures 2, 3)}

The jaws are very thin with a smooth masticatory process. The uniseriate radula is composed of 85 horseshoe-shaped teeth with three strong lateral denticles on either side of the median cusp (Figure 2A, B). The salivary glands are located just in front of the buccal bulb. They have a globular appearance opening into the oesophagus via a thin duct. Furthermore, above and at the posterior end of the salivary glands, there are three rounded giant cells. The pedal gland lies at the anterior part of the foot and around the oral opening. It is composed of numerous semispherical follicles.

The reproductive system is androdiaulic (Figure 3). The hermaphroditic gland is granulate, appearing as a compact mass clearly visible under the mantle. It is connected with the ampulla by a narrow hermaphroditic duct. The ampulla is large, thick and elongate. The rather long, postampullary duct splits into the vas deferens and the oviduct. The vas deferens begins as a large pyriform prostate gland and then tapers into a long and thin vas deferens with several loops and entering into the muscular penial bulb. Within the penial bulb is the elongate, conical and unarmed penis (Figure 2B, C). The oviduct is rather wide and elongated, forming a U-shaped loop before it dilates into the seminal receptacle, a spacious sac similar in length and width 
to the prostate gland. It continues with the vagina, which is short and slender. The female glands are very well developed and open together with the vagina.

\section{Molecular data (Figure 4)}

As indicated in Table 1, some gene fragments were not available for the analysis; in particular some nuclear fragments of the gene $\mathrm{H} 3$ and some $16 \mathrm{~S}$ fragment for some isolated species of Doto are missing. After alignment $1472 \mathrm{bp}$ were used. We obtained 18 new sequences; 6 for H3, 6 for COI and 6 for 16S. The saturation plots of uncorrected differences against corrected sequence divergence divided by codon indicated no saturation for any gene (not shown). Figure 4 shows the phylogenetic hypothesis based on the combined data set represented by BI.

Figure 4 clearly indicates that $D$. splendida sp. nov. represents a distinct lineage and that it clusters with two eastern Pacific (from the Pacific coast of Mexico and California, respectively) species rather than with any other Atlantic taxa. The available species of Doto constitute a clade with the maximum support $(\mathrm{PP}=1 ; \mathrm{BS}=100)$. Doto pinnatifida, D. coronata, D. eireana, D. floridicola and D. koenneckeri form a well-supported clade $(\mathrm{PP}=0.98 ; \mathrm{BS}=78)$ while $D$. splendida sp. nov. clusters with $D$. columbiana and Doto sp. H $(\mathrm{PP}=0.99 ; \mathrm{BS}=72)$. The phylogenetic relationship of this clade with the one including D. antarctica, Doto sp. 2, Doto sp. 7, Doto sp. K and D. ussi $(\mathrm{PP}=0.98 ; \mathrm{BS}=87)$ is not resolved. DNA sequences for Doto rosea are not available, but the morphological differences highlighted below clearly separate $D$. rosea of the new species. The sister taxon to the genus Doto is not yet fully resolved. Figure 4 shows that Hancockia californica is closer than Notobryon or Dendronotus, but this relationship is not supported either by the analysis of Bayesian inference nor by maximum-likelihood analysis.

\section{Discussion}

Three species of the genus Doto have been reported from South Africa: Doto coronata (Gmelin, 1791), Doto pinnatifida (Montagu, 1804) and Doto rosea Trinchese, 1881 (Gosliner 1987; Zsilavecz 2007). However, none of the species previously mentioned were originally described from South Africa or nearby. Doto coronata was originally described from the Dutch coast (Gmelin 1791), Doto pinnatifida from the British Isles (Montagu 1804) and Doto rosea from the Mediterranean (Trinchese 1881). Gosliner (1987) and Zsilavecz (2007) recorded these three species for South African waters, specifically for the Cape Peninsula and False Bay. Nevertheless, these authors did not undertake any morphological or molecular study to confirm the correct identification of these taxa. Thompson et al. (1990) stated that the identity of the 'Doto rosea' recorded from Southern Africa by Barnard (1927) and illustrated by Gosliner (1987), is enigmatic. Barnard (1927) reported it as Doto cinerea, which is actually accepted as Doto rosea after Pruvot-Fol (1954) synonymized both species. However, Odhner (1936), Just and Edmunds (1985), Ballesteros et al. (1986) and Cervera et al. (1988, 2004) consider $D$. cinerea as a valid species, distinct from $D$. rosea. It should be noted that $D$. rosea (illustrated by Schmekel and Portmann 1982) has dark brown spots on the notum, while the South African specimens have opaque white spots (Gosliner 1987). Therefore, taking into account the scarcity of morphological and molecular studies that exist within this genus, in this paper we simply assume that those 


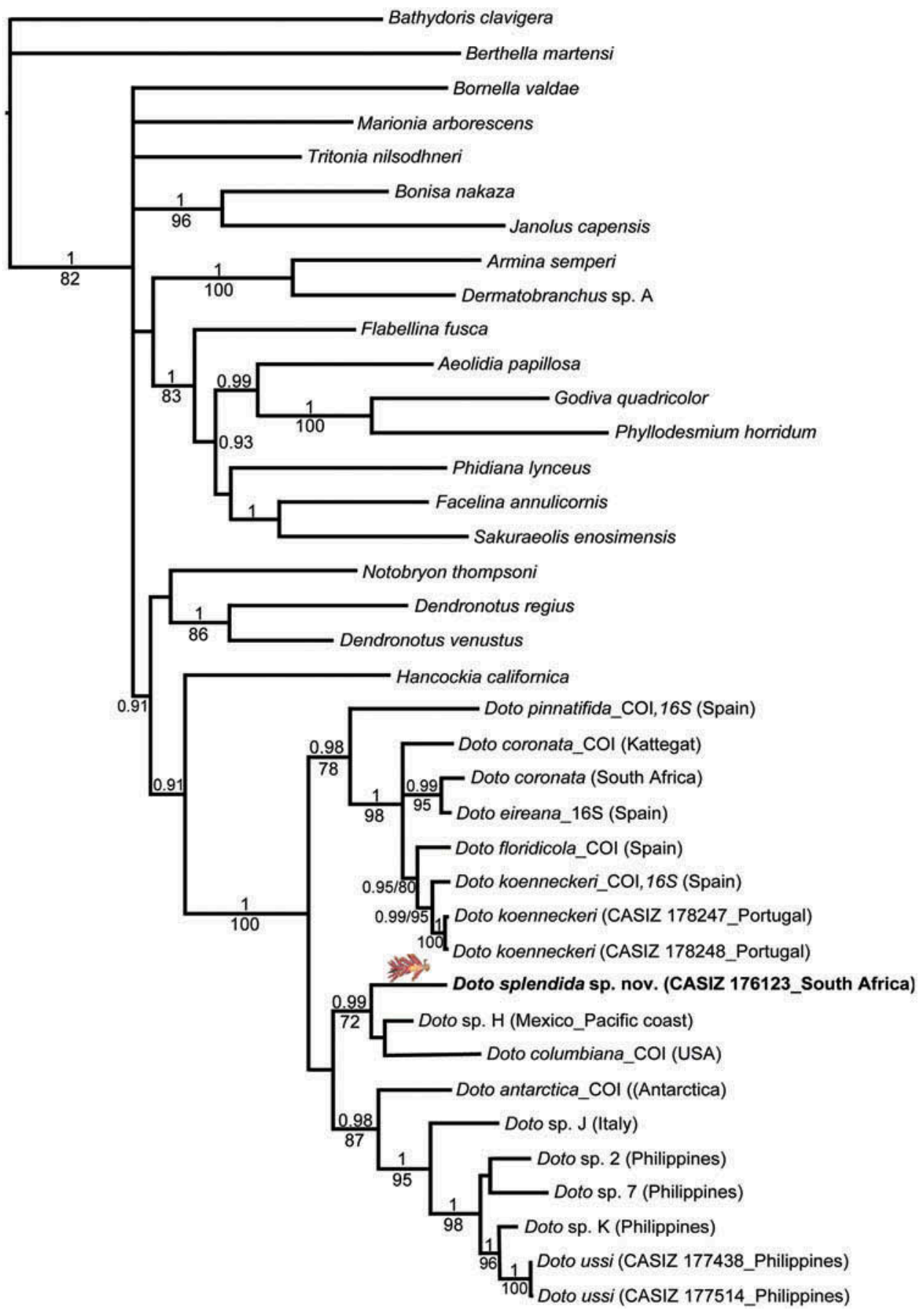

Figure 4. Phylogenetic hypothesis based on the combined data set $(\mathrm{COI}+16 \mathrm{~S}+\mathrm{H} 3)$ inferred by Bayesian analysis (BI). Numbers above branches represent posterior probabilities from BI. Numbers below branches indicate bootstrap values for ML. 
identifications by Gosliner (1987) and Zsilavecz (2007) are correct to compare them with Doto splendida sp. nov. However, it is obvious that detailed descriptions, with good pictures and internal structures as well as molecular data, are sorely needed to improve our knowledge within this baffling group of nudibranchs.

Both the molecular phylogenetic tree based upon mitochondrial and nuclear markers shown in Pola and Gosliner (2010), as well as our new results (Figure 4), clearly indicate that $D$. splendida sp. nov. is a distinctly different species from $D$. pinnatifida and $D$. coronata, based on the fact that it is nested in a clade together with two eastern Pacific species rather than with these other two Atlantic species. Regarding D. coronata, our analysis demonstrates that whether specimens from South Africa are well identified as D. coronata or not, both South African and North Sea specimens are different from our new species. DNA sequences for Doto rosea are not available at this time, but the morphological differences highlighted below also clearly distinguish $D$. rosea from the new species.

Comparison among D. splendida sp. nov., Doto coronata, D. pinnatifida and D. rosea based on morphological characters (Figure 5)

Doto coronata is a small nudibranch that attains $15 \mathrm{~mm}$ in extended length but usually does not exceed 10-12 mm (Thompson and Brown 1976, 1984) (Figure 5A, B). Doto
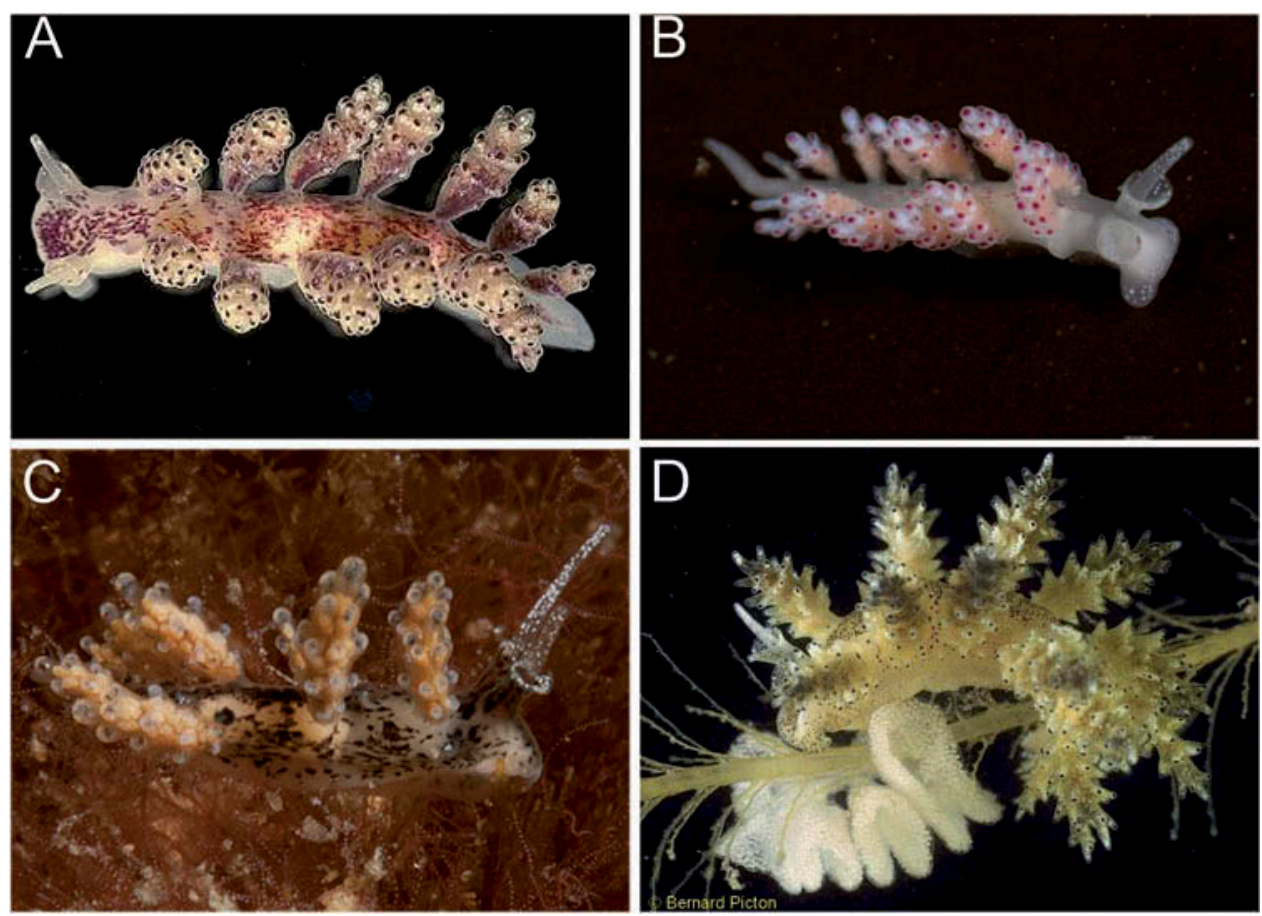

Figure 5. Living specimens. (A) Doto coronata (Gmelin, 1791). Specimen from Northern Ireland. Photo by Bernard Picton; (B) Doto cf. coronata. Specimen from South Africa, Cape Province, Oudekraal. Photo by T.M. Gosliner; (C) Doto rosea Trinchese, 1881. Specimen from Catalunia, Spain Photo by Antoni López-Arenas; (D) Doto pinnatifida (Montagu, 1804). Specimen from Northern Ireland. Photo by Bernard Picton. 
rosea (Figure 5C) was originally described by Trinchese (1881) with a maximum length of $8 \mathrm{~mm}$. Thompson et al. (1990) studied specimens of 5 and $6 \mathrm{~mm}$ but Schmekel and Portmann (1982) studied specimens of $12 \mathrm{~mm}$. It should be noted that the South African specimens of $D$. coronata lack the dark spots that are present in European specimens. Doto pinnatifida is larger than the previous species, reaching 29-30 mm (Thompson and Brown 1976, 1984; Zsilavecz 2007) (Figure 5D). Therefore, with respect to body size, D. pinnatifida is the only species that may be compared to the new species. Nonetheless, the colour of the body, cerata and digestive gland branches is completely different in all of them (Figure 5). The original description of $D$. pinnatifida says 'colour gray, spotted with olive green; blue gray papillae marked with a black spot at their tip: the stem or center part of the peduncle is a mixture of olive green and rufous brown' (Montagu 1804, table VII, figures 2, 3). Surprisingly, this is not the colour that appears in other descriptions of the species (Thompson and Brown 1976, 1984; Schmekel and Kress 1977; Picton and Morrow 1994) and is not shown in the photographs of the specimens from South Africa (Gosliner 1987; Zsilavecz 2007). No trace of olive green is found in those descriptions. After Montagu (1804) all pictures and colour description are similar to those found in Thompson and Brown (1976, p. 76): "pale fawn with dark brown to black mottling above: conspicuous dark brown spots around the rim of each rhinophore sheath and on the tips of small tubercles down each side of the body; cerata with tubercles each of which terminates in a dark brown or black spot'. Specimens illustrated from South Africa (Gosliner 1987; Zsilavecz 2007) are white with some occasional red spots and streaks along the mid-line of the body. The tip of each ceratal tubercle is generally black. Doto coronata and $D$. rosea also differ in colour from $D$. splendida sp. nov. Doto coronata is pale yellow or white with red or purplish pigment above, with streaks along the mid-line of the dorsum or covering much of it and also often parts of the sides. The cerata are pale and bear tubercles ending with a dark red spot (Gmelin 1791; Alder and Hancock 1845-1855; Lemche 1976; Thompson and Brown 1976, 1984; Gosliner 1987; Zsilavecz 2007). Figure 5A shows a specimen from Northern Ireland and Figure 5B shows the specimen collected in South Africa and sequenced in this study. In the original description of Doto rosea (Figure 5D), Trinchese (1881) stated that its body colour is yellow, dotted with small black dots or very dark ochre. Besides, the colour of the digestive gland branches in these three species is very different from $D$. splendida sp. nov., which is intense pink. In short, whether the identifications of the specimens observed in different parts of the world are correct or not, the colour of these three species differs widely from the new species.

The number of pairs of cerata and the number of tubercles per ceras are not very different among species. However, pseudobranchs are indistinct in D. coronata and D. pinnatifida (Thompson and Brown 1984) whereas they are present in D. rosea and D. splendida sp. nov. Thompson et al. (1990) described a simple flap-like pseudobranch but Schmekel and Portmann (1982) mentioned that the pseudobranch had branches. In our new species, each pseudobranch has at least 4-5 ramifications of varying lengths.

Regarding the radula, no SEM pictures of the teeth exist for these species. A few drawings and short descriptions are found in several older papers (Pruvot-Fol 1954; Kress 1968; Schmekel and Kress 1977; Schmekel and Portmann 1982; Thompson and Brown 1984; Thompson et al. 1990) but, in general, no pictures or drawings of the specimens are linked to those descriptions. Therefore, it is almost impossible to make 
good comparisons between the radula of these three species. It seems that the number of rows of teeth is quite variable $(n \times 0.1 .0)$, since $n$ goes from 51 to 68 in $D$. coronata (Schmekel and Kress 1977; Thompson and Brown 1984; Thompson et al. 1990), from 55 to 100 in D. pinnatifida (Miller 1958; Schmekel and Kress 1977; Thompson and Brown 1984) and from 75 to 101 in D. rosea (Schmekel and Portmann 1982; Thompson et al. 1990). Our paratype specimen of D. splendida sp. nov. has 85 teeth. The real problem with radular descriptions is that each of these descriptions is different regarding the number and size of the subsidiary denticles of the median cusp. For example, in $D$. coronata the descriptions vary from 'one (sometimes two) robust subsidiary denticle present on each side of the median cusp' (Thompson et al. 1990, p. 394), '3-5 subsidiary denticles present on each side of the median cusp' (Kress 1968, p. 472) to ' 3 subsidiary denticles present on each side of the median cusp' (Thompson and Brown 1984, p. 27). For D. pinnatifida, Thompson and Brown (1984) described each tooth as having 'a slender erect cusp, flanked on either side by up to 5 irregular, tiny, subsidiary denticles' (p. 35). The same apparent variation occurs in $D$. rosea, for which descriptions by the different authors are as follows: 'One subsidiary denticle present on each side of the stout median cusp' (Thompson et al. 1990, p. 399, for specimens from Greece); 'two prominent sharp denticles on each side of the median cusp' (Thompson et al. 1990, p. 399, for specimens from Italy); and '2 or 3 denticles on one side and 3 or 4 on the other' (Schmekel and Portmann 1982, p. 168; specimens from Naples). All these different descriptions are considered today as variation within the same species but easily could reflect different cases of cryptic species (Morrow et al. 1992; Pola et al. 2012, 2014; Carmona et al. 2014). For future comparisons, our species clearly has 85 horseshoe-shaped teeth with three strong lateral denticles on either side of the median cusp (Figure 2A, B).

Comparisons among reproductive system are not feasible since very few of them have been fully or even partially described. For example, the reproductive systems of $D$. pinnatifida is unknown. Trinchese (1881) described and figured the genitalia of $D$. costae but the drawing is impossible to interpret (table LX, figure 2). Odhner (1922) described and figured a long-stalked receptaculum seminis opening into the vestibulum in D. coronata. Schmekel and Portmann (1982, Abb. 7.41a-f) depicted schematic arrangements of the reproductive systems of $D$. acuta, D. coronata, D. doerga, $D$. floridicola, D. paulinae and $D$. rosea. Differences can be found among these schemes. In all species they depicted, except $D$. doerga, they illustrated a separate duct for the recetaculum seminis rather than the receptaculum seminis being a swelling of the vaginal duct, as in $D$. splendida. No trace of distinct duct with a terminal receptaculum is present in D. splendida (Figure 3). Other differences are shown in these schemes as the length and curvature of the vas deferens, the size of the penial bulb and also the length and form of the duct to the receptaculum seminis, when present. These differences could be used to separate species but were not used by subsequent authors. MacFarland (1966) described and figured in detailed the reproductive system of Doto varians MacFarland, 1966. This reproductive system is very similar to $D$. splendida sp. nov. However, the oviduct forms a U-shaped loop instead of two loops as in our species. Also, both the vas deferens and the vagina appear shorter than in $D$. splendida sp. nov. Marcus (1961) also depicted the reproductive systems of $D$. columbiana (O’Donoghue, 1921, D. amyra Marcus, 1961, Doto ganda Marcus, 1961, Doto kya Marcus, 1961 and Doto wara Marcus, 1961. All of these have a similar configuration of reproductive organs to $D$. doerga and $D$. splendida and lack a 
distinct duct with a terminal receptaculum seminis. However, in these five species from the Pacific coast of North America, the receptaculum is situated at the distal end of the vagina while in $D$. doerga and $D$. splendida the receptaculum is more basal near the gonopore. It is also important to note that the only described species with this reproductive anatomy, other than $D$. splendida, for which molecular data are also available, is $D$. columbiana. Interestingly, these species are found in the same clade, suggesting that reproductive anatomy found in these species may also be an indicator of phylogenetic relatedness.

These few examples of comparisons among radulae and reproductive systems demonstrate that these features should always be entirely described in every single species of Doto. Small differences could represent intra-specific variability but more likely they could represent different species and thus, they could be very useful to discriminate among species. Therefore, detailed morphological studies, when combined with molecular studies, provide different lines of evidence that greatly aid species delimitation.

Recent molecular studies on heterobranch gastropods (Carmona et al. 2011, 2014; Cooke et al. 2014; Pola et al. 2014; Padula et al. 2014), especially when combined with detailed morphological studies, have revealed the presence of numerous cryptic species. These molecular markers provide compelling new tools to facilitate rapid species delimitation and recognition of previously undetected biodiversity.

\section{Acknowledgements}

We thank our South African colleagues at the South African Museum, Wayne Florence and Elizabeth Hoensen, for their support and providing us facilities at the Museum. We also thank Guido Zsilavecz, Georgina Jones and Peter Southwood for their tremendous kind assistance, enthusiasm and support for fieldwork and their dedication to exploring the marine biodiversity of southern Africa.

\section{Disclosure statement}

No potential conflict of interest was reported by the authors.

\section{Funding}

The field research that permitted collection of these specimens was funded by the National Science Foundation Partnership for Enhancing Expertise in Taxonomy [DEB 0329054] Phylogeny of the Nudibranchia.

\section{References}

Akaike H. 1974. A new look at the statistical model identification. IEEE Trans Automat Contr. 19:716-723.

Alder J, Hancock A. 1845-1855. A monograph of the British nudibranchiate Mollusca: with figures of all the species. London: Ray Society.

Ballesteros M, Barrajon A, Luque AA, Moreno D, Talavera P, Templado J. 1986. Contribución al conocimiento de los gasteropodos marinos de Almeria. Iberus. 6:39-55.

Barnard K. 1927. South African nudibranch Mollusca, with descriptions of new species, and a note on some specimens from Tristan d'Acunha. Ann S Afr Mus. 25:171-215. 
Carmona L, Bhave V, Salunkhe R, Pola M, Gosliner TM, Cervera JL. 2014. Systematic review of Anteaeolidiella (Mollusca, Nudibranchia, Aeolidiidae) based on morphological and molecular data, with a description of three new species. Zool J Linn Soc Lond. 171:108-132.

Carmona L, Gosliner TM, Pola M, Cervera JL. 2011. A molecular approach to the phylogenetic status of the aeolid genus Babakina Roller, 1973 (Nudibranchia). J Mollus Stud. $77: 417-422$.

Castresana J. 2000. Selection of conserved blocks from multiple alignments for their use in phylogenetic analysis. Mol Biol Evol. 17:540-552.

Cervera JL, Calado G, Gavaia C, Malaquias MAE, Templado J, Ballesteros M, GarcíaGómez JC, Megina C. 2004. An annotated and updated checklist of the opisthobranchs (Mollusca: Gastropoda) from Spain and Portugal (including islands and archipelagos). Bol Inst Español Oceanogr. 20:1-95.

Cervera JL, Templado J, Garcia-Gomez JC, Ballesteros M, Ortea JA, Garcia FJ, Ros J, Luque AA. 1988. Catalogo actualizado y comentado de los Opistobranquios (Mollusca, Gastropoda) de la Peninsula Iberica, Baleares y Canarias, con algunas referencias a Ceuta y la Isla de Alboran. Iberus. supplement 1:1-84.

Cooke S, Hanson D, Hirano Y, Ornelas-Gatdula E, Gosliner TM, Chernyshev AV, Valdés Á. 2014. Cryptic diversity of Melanochlamys sea slugs (Gastropoda, Aglajidae) in the North Pacific. Zoologica Scripta. 43:351-369.

Cuvier G. 1795. Second Mémoire sur l'organisation et les rapports des animaux à sang blanc, dans lequel on traite de la structure des Mollusques et de leur division en ordre, lu à la société d'Histoire Naturelle de Paris, le 11 prairial an troisième [Second Memory of the organization and reports of white-blooded animals, in which deals with the structure of molluscs and their division in order, read in the Natural History Society of Paris, on 11 Prairial third]. Magazin Encyclopédique, ou Journal des Sciences, des Lettres et des Arts. 2:433-449.

Cuvier G. 1817. Le Règne Animal, distribué d'après son organisation, pour servir de base à 1'historie naturelle des animaux et d'introduction à l'anatomie comparée, tome II, contenant les reptiles, les poissons, les mollusques et les annélides [Animal Kingdom, distributed on its individual organization, as a basis for the natural historie animals and Introductory to the comparative anatomy, volume II, containing reptiles, fish, mollusks and annelids]. Paris: Deterville.

Drummond AJ, Ashton B, Cheung M, Heled J, Kearse M, Moir RSSH, Thierer T, Wilson A. 2009. Geneious v4.6 [Internet]. [cited 2015 Jan 15]. Available from: http://www.geneious. $\mathrm{com} /$

Gray JE. 1853. Revision of the families of nudibranch mollusks, with the description of a new genus of Phyllidiadae. Ann Mag nat Hist., series 2. 11:218-221.

Gmelin JF. 1791. In: Linnaeus' Systema Naturae, per regna tria naturae: secundum classes, ordines, genera, species, cum characteribus, differentiis, synonymis, locis. ed. 13, Lipsiae: 13103.

Gosliner TM. 1987. Nudibranchs of Southern Africa. A guide to the opisthobranch mollusks of southern Africa. Monterey: Sea Challengers; $136 \mathrm{pp}$.

Gosliner TM, Behrens DW, Valdés Á. 2008. Indo-Pacific nudibranchs and sea slugs. A field guide to the world's most diverse fauna. Gig Harbor, WA: Sea Challengers Natural History Books; p. 1-426.

Just H, Edmunds M. 1985. North Atlantic nudibranchs (Mollusca) seen by Henning Lemche, with additional species from the Mediterranean and the north east Pacific. Ophelia. Suppl 2:1-170.

Katoh K, Asimenos G, Toh H. 2009. Multiple alignment of DNA sequences with MAFFT. In bioinformatics for DNA sequence analysis edited by D. Posada. Methods Mol Biol. 537:39-64. 
Kress A. 1968. Untersuchungen zur Histologie, Autotomie und Regeneration dreier DotoArten Doto coronata, D. pinnatifida, D. fragilis (Gastropoda, Opisthobranchiata). Rev Suisse Zool. 75:235-303.

Lemche HM. 1976. New British species of Doto Oken, 1815 (Mollusca: Opisthobranchia). J Mar Biol Assoc UK. 56:691-706.

MacFarland FM. 1966. Studies of opisthobranchiate mollusks of the Pacific coast of North America. Mem Calif Acad Sci. 6:1-546.

Maddison DR, Maddison WP. 2005. MacClade 4., v. 4.08 for OSX. Sunderland, MA: Sinauer Associates.

Marcus E. 1961. Opisthobranch molluscs from California. Veliger. 3:1-84.

Miller M. 1958. Studies on the nudibranchiate Mollusca of the Isle of Man [dissertation]. Liverpool (UK): University of Liverpool.

Montagu G. 1804. Description of several marine animals found on the south coast of Devonshire. Trans Linn Soc London. 7:61-85.

Morrow CC, Thorpe JP, Picton BE. 1992. Genetic divergence and cryptic speciation in two morphs of the common subtidal nudibranch Doto coronata (Opisthobranchia, Dendronotacea, Dotoidae) from the northern Irish Sea. Mar Ecol-Progr Ser. 84:53-61.

Nylander JAA. 2004. MrModeltest v2.3. Program distributed by the author. Evolutionary Biology Centre, Uppsala University.

Odhner NH. 1922. Norwegian opisthobranchiate Mollusca in the collections of the Zoological Museum of Kristiania. Nyt Mag Naturvidensk. 60:1-47.

Odhner NH. 1936. Nudibranchia Dendronotacea-A revision of the system. Mem Mus R Nat Hist Belg. 2:1057-1128.

O`Donoghue CH. 1921. Nudibranchiate Mollusca from the Vancouver Island región. Trans R Can Inst. 13:147-209.

Oken L. 1815. Okens Lehrbuch der Naturgeschichte, Dritter Theil, Zoologie, Erste Abtheilung Fleischlose Thiere [Oken's textbook of Natural History, Third part, Zoology, First division herbivores animals]. Jena: Schmid \& Co.

Ortea JA. 1982. Una nueva especie de Doto (Mollusca, Dendronotacea) de las islas Comores [A new species of Doto (Mollusca, Dendronotacea) from the Comores Islands. Cah Biol Mar. 23:1-7.

Ortea JA, Bouchet P. 1989. Description de deux nouveaux Doto de Méditerranée occidentale (Mollusca, Nudibranchia). Bollettino Malacologico. 24:261-268.

Padula V, Araújo AK, Matthews-Cascon H, Schrödl M. 2014. Is the Mediterranean Nudibranch Cratena peregrina (Gmelin, 1791) present on the Brazilian coast? Integrative species delimitation and description of Cratena minor n. sp. J Mollus Stud. 1-10. doi:10.1093/mollus/eyu052

Picton BE, Morrow C. 1994. A field guide to the nudibranchs of the British Isles. London: Immel Publishing; 143 pp.

Pola M, Camacho-García YE, Gosliner TM. 2012. Molecular data illuminate cryptic nudibranch species: the evolution of the Scyllaeidae (Nudibranchia: Dendronotina) with a revision of Notobryon. Zool J Linn Soc. 165:311-336.

Pola M, Gosliner TM. 2010. The first molecular phylogeny of cladobranchian opisthobranchs (Mollusca, Gastropoda, Nudibranchia). Mol Phylogenet Evol. 56:931-941.

Pola M, Roldán P, Padilla S. 2014. Molecular data on the genus Okenia (Nudibranchia: Goniodorididae) reveal a new cryptic species from New South Wales (Australia). J Mar Biol Assoc UK. 94:587-598.

Pruvot-Fol A. 1954. Faune de France, Mollusques opisthobranches. Paris: Lechevalier; p. $1-460$.

Ronquist F, Huelsenbeck JP. 2003. MrBayes 3: Bayesian phylogenetic inference under mixed models. Bioinformatics. 19:1572-1574. 
Schmekel RL, Kress A. 1977. Die Gattung Doto (Gastropoda: Nudibranchia) im Mittelmeer und Armelicanal, mit Beschreibung von Doto acuta, n. sp. Malacologia. 16:467-499.

Schmekel RL, Portmann A. 1982. Opisthobranchia des Mittelmeeres, Nudibranchia und Saccoglossa. Berlin: Springer-Verlag; p. 1-410.

Schrödl M, Wägele H, Willan RC. 2001. Taxonomic redescription of the Doridoxidae (Gastropoda: Opisthobranchia), an enigmatic family of deep water Nudibranchs, with discussion of basal nudibranch phylogeny. Zool Anz. 240:83-97.

Stamatakis A. 2006. RAxML-VI-HPC: maximum likelihood-based phylogenetic analyses with thousands of taxa and mixed models. Bioinformatics. 22:2688-2690.

Swofford DJ. 2002. PAUP*: phylogenetic analysis using parsimony (*and other methods). Version 4. Sunderland (MA): Sinauer.

Thompson TE, Brown GH. 1976. British opisthobranch molluscs. Mollusca: Gastropoda. Synopses of the British fauna (new series) no. 8. London: Linnean Society; 203 pp.

Thompson TE, Brown GH. 1984. Biology of opisthobranch molluscs 2. London: Ray Society; Vol. 156, 229pp.

Thompson TE, Cattaneo R, Wong YM. 1990. Eastern Mediterranean Opisthobranchia: Dotidae (Dendronotoidea), Arminidae and Madrellidae (Arminoidea). J Molluscan Stud. 56:393-413.

Trinchese S. 1881. Aeolididae e famiglie affini del Porto di Genova. Part 2. Anatomia, fisiologia, embriologia delle Phyllobranchideae, Hermaeidae, Aeolididae, Proctonotidae, Dotonidae del Porto di Genova. Mem Cl Sci Fis. 11:1-142.

Zsilavecz G. 2007. Nudibranchs of the Cape Peninsula and False Bay. Cape Town: Southern Underwater Research Group press. 